\title{
Neuroendocrine breast carcinoma metastasis to the brain
}

\author{
Luca Zanin, ${ }^{1}$ Pietro Luigi Poliani, ${ }^{2}$ Roberto Liserre, ${ }^{3}$ Pier Paolo Panciani ${ }^{1}$
}

${ }^{1}$ Neurosurgery, Spedali Civili University Hospital of Brescia, Brescia, Italy

${ }^{2}$ Department of Molecular and Translational Medicine, Pathology Unit, University of Brescia School of Medicine, Brescia, Italy

${ }^{3}$ Neuroradiology, Spedali Civili University Hospital of Brescia, Brescia, Italy

Correspondence to Dr Pier Paolo Panciani, pierpaolo.panciani@gmail.com

Accepted 23 February 2019

\section{DESCRIPTION}

A 53-year-old woman presented to our hospital with visual impairment and diplopia. The symptoms appeared about 2 weeks before. The patient had a diagnosis of neuroendocrine breast carcinoma (NBC) 10 years earlier. The cerebral MR showed the presence of a brain tumour with neuroradiological features suggestive of both high-grade glioma and primitive neuroectodermal tumour (figure 1). We performed a subtotal resection that led to transient aphasia and right hemiparesis.

Histological examination revealed metastasis from poorly differentiated neuroendocrine carcinoma composed of clusters of cells with abundant cytoplasm and vesicular nuclei with finely granular chromatin and high number of mitoses (figure 2A,B). Immunostains showed intense and diffuse positivity for pan-cytokeratin and synaptophysin (figure 2C, lefts panels), suggesting their neuroendocrine phenotype, and positivity for E-Cadherin and GATA-3, confirming the breast primitivity (figure $2 \mathrm{C}$, right panels). Assessment of prognostic and predictive factors showed diffuse positivity for oestrogen receptors, very few positive nuclei for progesterone receptors (figure $2 \mathrm{D}$, left panels) and low expression of c-erbB-2 (Her2-neu) (score 1). Proliferation index was very high (figure 2D, right panels).
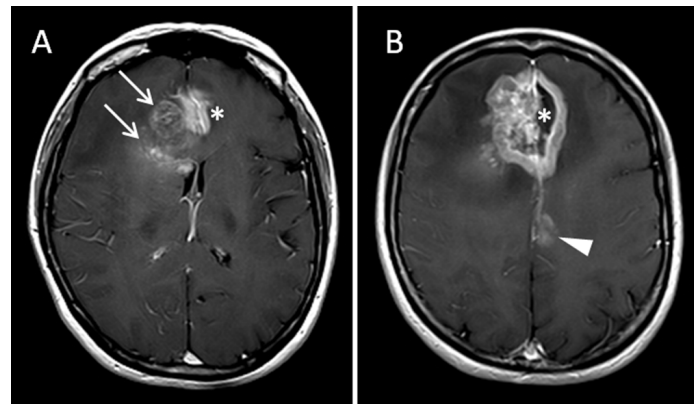

Figure 1 Postgadolinium (Gd) T1-weighted images of two axial contiguous sections showing a highly inhomogeneous lesion constituted of: a right paramedian partially necrotic intra-axial component in genu of corpus callosum and periventricular white matter with infiltrating pattern determining encasement of the right frontal horn (arrows in A); a thick ring-like enhancing midline component with necrotic core, predominantly extraaxial location and infiltration of a thickened falx cerebri (asterisk in A and B). A second intra-axial lesion is seen in left posterior cingulum (arrowhead in B) showing faint irregular enhancement with feathered borders, adjacent to the pathologically $\mathrm{Gd}$-enhancing falx.

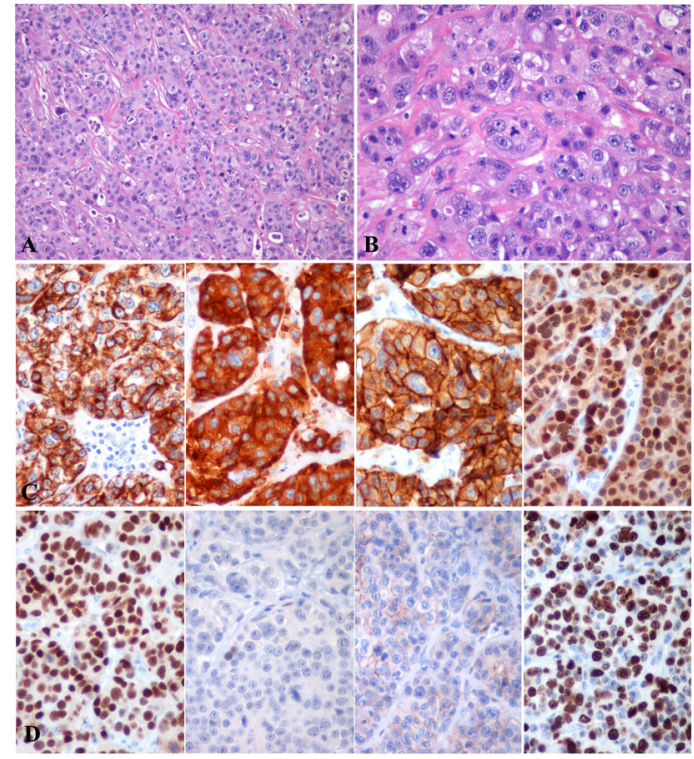

Figure 2 Histological features of poorly differentiated neuroendocrine carcinoma with solid nests of atypical cells with abundant cytoplasm, vesicular nuclei and numerous mitotic figures (panel $A$ and $B, H \& E, \times 20$ and $\times 40$ original magnification, respectively); panel $C$ shows expression of pan-cytokeratin and synaptophysin (left two panels) and expression of E-Cadherin and GATA-3 (right panels); panel D shows immunostains for hormone receptors, oestrogen and progesterone (left two panels) and immunostains for c-erbB-2 and Ki67 (right two panels). All immunostains are from $\times 40$ original magnification.

Neuroendocrine tumours (NETs) are rare and usually affect lung, pancreas and gastrointestinal tract. ${ }^{1}$ Breast localisation is observed in less than $0.5 \%$ of cases. ${ }^{2}{ }^{3}$ NETs rarely metastasise to the brain. The literature reported only six cases of cerebral metastases of NETs, but none of these were an NBC. ${ }^{45}$ NBC was first described in 1977 and was characterised by the presence of positive neuroendocrine markers in over $50 \%$ of the tumour cells. According to the 2012 WHO classification, NBC was subclassified into well-differentiated NET, poorly differentiated neuroendocrine carcinoma and invasive breast carcinoma with neuroendocrine differentiation, regardless of the percentage of neuroendocrine markers.

Our case showed that NBC may metastasise to the brain. Moreover, we observed that in case of NBC cerebral metastasis, the neuroradiological pattern is absolutely atypical and may look like both glioblastoma and neuroectodermal tumour. 


\section{Learning points}

Neuroendocrine breast carcinoma (NBC) is a rare tumour that may metastasise to the brain even over 10 years.

- NBC cerebral metastases have an atypical neuroradiological pattern with features of both high-grade glioma and primitive neuroectodermal tumour.

Contributors LZ: planning, interpretation of data and reporting. LP: planning of the paper and data analysis. RL: reporting and acquisition of data. PPP: conception, design and conduct of the work.

Funding The authors have not declared a specific grant for this research from any funding agency in the public, commercial or not-for-profit sectors.
Competing interests None declared.

Patient consent for publication Obtained.

Provenance and peer review Not commissioned; externally peer reviewed.

\section{REFERENCES}

1 Modlin IM, Moss SF, Gustafsson BI, et al. The archaic distinction between functioning and nonfunctioning neuroendocrine neoplasms is no longer clinically relevant. Langenbecks Arch Surg 2011;396:1145-56.

2 Adams RW, Dyson P, Barthelmes L. Neuroendocrine breast tumours: breast cancer or neuroendocrine cancer presenting in the breast? Breast 2014;23:120-7.

3 Rosen LE, Gattuso P. Neuroendocrine Tumors of the Breast. Arch Pathol Lab Med 2017; 141:1577-81

4 Sundar IV, Jain SK, Kurmi D, et al. Malignant metastatic carcinoid presenting as brain tumor. Asian I Neurosurg 2016;11:314

5 Maiuri F, Cappabianca P, Del Basso De Caro M, et al. Single brain metastases of carcinoid tumors. J Neurooncol 2004:66:327-32.

Copyright 2019 BMJ Publishing Group. All rights reserved. For permission to reuse any of this content visit

https://www.bmj.com/company/products-services/rights-and-licensing/permissions/

BMJ Case Report Fellows may re-use this article for personal use and teaching without any further permission.

Become a Fellow of BMJ Case Reports today and you can:

- Submit as many cases as you like

- Enjoy fast sympathetic peer review and rapid publication of accepted articles

- Access all the published articles

Re-use any of the published material for personal use and teaching without further permission

For information on Institutional Fellowships contact consortiasales@bmjgroup.com

Visit casereports.bmj.com for more articles like this and to become a Fellow 